\title{
Issues at the Rural-Urban Fringe: A Policy Overview of Maintaining Land in Agriculture ${ }^{1}$
}

Rodney L. Clouser and W. David Mulkey²

\section{Introduction}

This fact sheet is one in a series intended to familiarize readers with land use issues at the rural-urban fringe and to identify the techniques that various states, counties, and communities are utilizing to maintain land in agricultural use. Collectively, the fact sheets will provide an overview of common land use conflicts, laws that influence land use at the rural-urban fringe, situational and policy issues related to land use, and the techniques used by governments to deal with these issues.

\section{Background}

For the past two decades Florida citizens and governments have been actively involved in addressing land use issues. Planning efforts have been mandated by the state for over 30 years with increased emphasis at the state, county, and municipal level for the past 20 years. A review of some of the laws related to planning at the rural-urban fringe is found in EDIS publication FE550, Issues at the Rural-Urban Fringe: Florida State Laws Related to Land Use (http://edis.ifas.ufl.edu/FE550). As a result of these planning laws and citizen interest, various policies have been adopted to address concerns with agricultural land retention. These concerns and various policy options are neither new nor unique to Florida - they have been considered by state, county, and municipal governments throughout the United States.

The goals of agricultural land retention programs are simple and straightforward: to halt or slow the conversion of agricultural land to non-agricultural uses. The logic of programs to address agricultural land conversion issues is more complex. A summary of issues raised and the need for agricultural land retention are covered in EDIS publication FE551, Issues at the Rural-Urban Fringe: The Land Use Debate--Situational Background (http://edis.ifas.ufl.edu/FE551). A review of U.S. agricultural retention programs reveals that types of programs, their effectiveness, costs, and equity (equal treatment of equals) vary widely.

\section{The Land Market}

Assessment of various agricultural land programs can best be accomplished by understanding and exploring the manner in which land is currently

1. This is EDIS document FE552, a publication of the Department of Food and Resource Economics, Florida Cooperative Extension Service, Institute of Food and Agricultural Sciences, University of Florida, Gainesville, FL. This document is one of a series entitled "Issues at the Rural Urban Fringe". Published July 2005. Please visit the EDIS website at http://edis.ifas.ufl.edu.

2. Rodney L. Clouser, Professor and Public Policy Specialist, and W. David Mulkey, Professor and Associate Chair, Department of Food and Resource Economics, Florida Cooperative Extension Service, Institute of Food and Agricultural Sciences, University of Florida, Gainesville, FL. 
allocated for various uses. One component of the land market is the seller-buyer relationship. Landowners exert significant control over the property they own. Interactions between sellers and buyers of land in any locality (nation, state, county, etc.) create the market for land. Parcels bought and sold in the marketplace create a set of land uses such as housing, agriculture, roads, parks, etc. Buying, selling, and use of land are heavily influenced by supply-and-demand factors such as location, soil types, climate, water availability, transportation systems, and input suppliers. These factors relate to both land use and land value. In general, the desire of both the seller and buyer is for land to have the highest valuable use.

Landowners, however, do not act independently in the land market. The land market is also subject to some control by government. Governmental control in the land market can be divided into administrative, legislative, and constitutional constraints.

Administrative and legislative controls are closely intertwined. Administrative rules are often put into place to make certain the land market works in an orderly fashion. Examples of these rules might include laws related to contracts, recording deeds, and land use development regulations. Legislative actions have greater impact and actively control or influence the land market. Examples of legislative actions include zoning laws, pollution control, water use allocation, and land taxes. However, not even municipal, county, or state governments are self-governing in their actions related to the land market. Actions by administrative and governmental bodies are constrained by constitutional provisions at state and national levels. In Florida, for example, the title to land under navigable water is held by the state and can only be sold by the state if in the public interest.

What has been described is a land market that is a system of three distinct decision groups: individual landowners, governmental bodies that control administrative and legislative laws/rules, and judicial bodies that oversee and interpret constitutional controls at the state and national level. Actions by any of these groups affect the allocation of land, including the ultimate amount of land used for various purposes. What is known with certainty is that landowners react to changing rules and regulations, governments react to changing political pressures and societal needs, and constitutional changes result from amendments and judicial interpretations. Change at any of these three levels can influence actions of any or all three groups.

Even within the limitations of this three-tiered system, the land market typically allocates land to uses that yield higher market returns. However, this may be problematic with agricultural lands. There is concern that agricultural land is priced too low on the open market because some of the benefits from the land are not capitalized into the land price. An example might be benefits derived from agricultural land as open space. Other benefits of an "open market" include factors such as the value of water recharge areas, wildlife habitats, picturesque beauty of an open space, or use of the open space for "gray water" discharge (water below drinking grade standards) or recycling municipal yard waste. Most of these benefits accrue to the "public-at-large" and there are limited means to collect fees from those who benefit from the agricultural land providing these benefits. It is easier to collect fees from a municipality to recycle yard waste on privately-owned property than from tourists. In either case it is unlikely that the full value of the benefit received by the public-at-large can be accounted for in private market transactions.

Another problematic concern in the market allocation of agricultural land is that when price alone guides market transactions the probability of land use conflicts may increase. Assume you have five 100 -acre agricultural parcels (500 acres of agricultural land). Also assume there is demand for 100 acres of that land for a one-acre-lot size housing development. The market would encourage selling that land to the higher yielding return of housing. However, if the remaining 400 acres of land were intensively used in poultry and dairy operations it could be incompatible with new housing development. When this happens the typical approach is for administrative and legislative rules and laws to be enacted. Such restrictions may reduce the rate of return on agricultural land and encourage more rapid conversion to non-agricultural uses. Alternatively, restrictions on new housing developments to protect 
agricultural lands may reduce the value of the property for development.

Rapid growth (especially when agricultural property is a few miles away from the prime development area or full-scale development might be a decade away) can distort land prices. The thought process of the landowner might be that land values are considerably higher than initial investment cost; agricultural suppliers of feed, seed, fertilizer, and equipment are disappearing; and complaints from those nearby about noise and odor are increasing. With the future uncertain, disincentives to invest in capital items such as facilities and equipment can occur, inadvertently quickening the conversion of land to non-agricultural uses.

\section{Evaluating Policy Options}

There are numerous options for states, counties, and municipalities wanting to have some control over the allocation of land to agricultural uses. Eliminating restrictive measures that limit agricultural competitiveness or paying incentives to encourage current land uses could be options to consider. At the state and national levels, programs and policies encouraging technological innovation are possible. At the local level, growth could be discouraged through laws and policies. In some sections of the country several options have been adopted to encourage agricultural land uses.

The variety of land use options generally falls into the broad categories of fee simple purchase, preferential tax treatment, agriculture districts, purchase or transfer of development rights, agricultural zoning, cluster development, and conservation easements. There is no "one size fits all" program that works in every locality so each area has a somewhat unique mixture of policies to achieve desired goals regarding land use. While options are distinctive to each community, the three-tiered land market system is consistent among all localities and further highlights other factors to consider in evaluating agricultural land maintenance programs.

Most localities know it is essential that all citizens and governments understand clearly the goal of the land use policies being considered. This sounds simple, but is really very complex because of the "political" interests of individuals impacted by decisions and their desire to influence policies. An example might be improving equity (equal treatment of equals) in the local tax system. If this is the policy goal, then adopting preferential tax treatments might be the appropriate policy action. On the other hand, if the long-term goal is retention of land in agricultural use, preferential tax treatments might prove to be a dismal failure because the reduced tax burden is negligible relative to the sales price for development. While some local interest groups may view the policy goal as keeping land in agricultural use, other local interest groups may view the policy goal as retaining community open space, enhancing or improving environmental quality, reducing density levels, or expanding wildlife habitats. All these other goals may be commendable, but agriculture land maintenance programs may not represent the best way to achieve these outcomes. Without clearly identifying and articulating the ultimate policy goal, localities may find that adopting certain policies do not necessarily accomplish desired goals, or that poor policy decisions are no better than no policy decisions at all.

Another consideration must be the distribution of benefits and costs created by the adopted policies. Who pays for the programs and who benefits from the programs are not always the same. One example would be exclusive agricultural zoning that does not allow for any type of residential development. The beneficiary of exclusive agricultural zoning is the public-at-large because more production generally translates into stable or lower food prices or more open space. Who pays for the cost of this program? If the land cannot be profitably farmed nor sold, then the landowner pays the costs for the adopted policies. However, if the policy adopted by the local government was a fee simple purchase, or a development-right policy, or an easement policy, then the landowner would receive direct compensation. This might represent a more equitable approach to the landowner than exclusive zoning because of direct benefit payment.

When evaluating alternative agricultural land maintenance issues, land remaining in agriculture cannot be separated from the allocation of land in the 
community-at-large. Keeping the same amount of land in agriculture implies there is less land available for other uses in a growing locality. If the amount of rural or agricultural land remains the same, then there is less land to be used for housing, parks, roads, etc. Another factor to consider is that land use allocations are affected by a host of government policy decisions not always considered as land use policies. These government decisions include factors such as water, sewer, and electric utility patterns and extensions; local road systems development; and local tax incentives to encourage economic development in different areas of the community. Governments and other interested parties must assess all local policies that affect land use, not just those labeled "land use".

Agricultural land use is also subject to a number of issues beyond the control of local government. Pricing of agricultural inputs and prices received for commodities produced are influenced not only by local conditions, but by international and global conditions. It is entirely possible that local governments can enact reasonable and effective programs for agricultural land use but cannot ensure profitable or sustainable agriculture. When this happens they also cannot ensure agricultural production.

\section{Conclusion}

Maintaining land in agricultural use is a complex policy decision. It requires clearly understanding the goal behind enacted policies. Effective policy decisions also require understanding of the land market system, including the role of government at the local, state, and national level. Local land use decisions are also influenced by global market conditions and prices and these factors are often beyond the control of lower-level units of government. Achieving the desired outcome and goal for agricultural land maintenance programs is a challenging task.

\section{References}

Clouser, Rodney L, and Michael T. Olexa. 2005. Issues at the Rural-Urban Fringe: Florida State Laws Related to Land Use. Electronic Data Information Source (EDIS) FE550. Department of Food and
Resource Economics, University of Florida, Gainesville, FL. http://edis.ifas.ufl.edu/FE550.

Clouser, Rodney L. 2005. Issues at the Rural-Urban Fringe: The Land Use Debate--Situational Background. Electronic Data Information Source (EDIS) FE551. Department of Food and Resource Economics, University of Florida, Gainesville, FL.

http://edis.ifas.ufl.edu/FE551.

Mulkey, David, and Rodney L. Clouser. 1987. Maintaining Land for Agriculture: A Policy Overview. FRE 27. Department of Food and Resource Economics, University of Florida, Gainesville, FL. 